\title{
Morphometrical Characterization and Structural Indices of Indigenous Goats Reared in Two Production Systems in Sidama Zone, Southern Ethiopia
}

\author{
Amsale Hankamo ${ }^{1,}$, , Tariku Woldeyohannes ${ }^{1}$, Sandip Banerjee $^{2}$ \\ ${ }^{1}$ Department of Animal Science, Mizan Tepi University, Mizan Teferi and Tepi, Ethiopia \\ ${ }^{2}$ Department of Animal and Range Science, Hawassa University, Hawassa, Ethiopia \\ Email address: \\ amsalehakamo@gmail.com (A. Hankamo), tarikuw52@gmail.com (T. Woldeyohannes), sansoma2003@gmail.com (S. Banerjee) \\ *Corresponding author
}

To cite this article:

Amsale Hankamo, Tariku Woldeyohannes, Sandip Banerjee. Morphometrical Characterization and Structural Indices of Indigenous Goats Reared in Two Production Systems in Sidama Zone, Southern Ethiopia. International Journal of Animal Science and Technology.

Vol. 4, No. 1, 2020, pp. 6-16. doi: 10.11648/j.ijast.20200401.12

Received: January 24, 2020; Accepted: February 28, 2020; Published: May 29, 2020

\begin{abstract}
This study was conducted with the aim of morphometrical characterization and structural indices to assess type and function of indigenous goats reared in two production system in Sidama Zone, Southern Ethiopia. The study encompassed both qualitative and quantitative parameters which were taken from 780 head of adult goats of both sexes from age 1PPI to 4PPI. Age was estimated by dentition. The qualitative traits were assessed visually and recorded while; quantitative traits were assessed using self-devised equipment. Thirteen morphometrical measurements were taken per goat and from which also indices were calculated. Data collected by visual observation and linear measurements were analyzed by Statistical Package for Social Sciences (SPSS version, 20) and the value was considered significance at $\mathrm{P}<0.05$ and $\mathrm{P}<0.01$. The qualitative data were assessed by chi-square test. The observed coat color patterns in studied area for both sexes across the districts were plain. Most frequently observed coat color type from sampled goats at Aroresa district were brown and black while, most frequently observed coat color type at Lokabaya district were white. The results of morphometrical measurements indicated that Does age group of 1 and 2 and 3 and 4 reared at Aroresa district had higher value for most measured traits. Bucks age group 1 and 2 reared at Lokabaya district had higher value for their body length, chest girth, rump length, horn length, body weight, rump height and chest depth except rump width, face length and head width which is higher for the Buck in age group 1 and 2 reared at Aroresa district. The Bucks reared at Lokabaya district had higher values for their neck circumference and body weight while, the Bucks reared at Aroresa district had higher value for their head width. In generally, most morphometric traits were different between the goats reared in the studied districts and these variations indicate the possibilities for selection between the goats in the areas. The regression was done to regress body weight from linear body measurements for different age and sex groups separately. As a result from multiple regressions, chest girth, body length, chest depth and neck circumference were the best fitted models to predict body weight for different age and sex groups separately.
\end{abstract}

Keywords: Indigenous Goat, Morphometrical Measurements, Structural Indice

\section{Introduction}

Goats are amongst the most important livestock which sustain the livelihoods of the smallholder farmers, pastoralists and agro pastoralist alike [50]. They are reared for their multifarious roles viz. social security, income generation, milk, manure, chevon and skin to name a few [7, 42]. They are important livestock species especially in the lowland areas which is accompanied with frequent droughts [43]. According to [15], the population of goats in Ethiopia is estimated to be about 30.20 million heads. The tropical breeds of goats are moderately tolerant to many locally prevalent diseases and parasites, have good flocking instinct, ability to walk for long distances in search of feed, can endure drought like conditions besides can browse on forages which are otherwise unpalatable to large ruminants [29]. 
They are owned by the agrarian societies for whom this resource is critical for their family nutrition and income and important as secure form of investment, which happens to be the major farming activity on vast areas of natural grasslands in regions where crop production is sparse [38]. Characterization of native livestock genetic resources (based on morphological traits) are fundamental for the classification of any livestock resources, this classification is usually based on their size and shape which can be to some extent serve as economic indicators for the reasons why they are reared [36]. Morphometrical classification also known as phenotypic classification divided into both qualitative and quantitative traits. Assessment of the former being subjective and influenced by a few pairs of genes with major effects while the later is influenced by several pairs of genes both with major and minor effects $[31,6]$. The quantitative traits are influenced by the environment while the reverse was true for the qualitative traits [17]. It has evolved through many years of regular experimentation on the day-to-day life and available resources surrounding the community and is essential for maintenance of the genetic resources for the continued survival of the breed/type. According to [20], identifying and understanding of a genetic resource in a particular region and its development and proper use of the associated diversity is a global responsibility. Characterization of genotype has been recognized as the primordial approach to the sustainable use of livestock genetic resource [31]. The characterization of native genetic resources depends on the knowledge of the variation of morphological traits, which have played very fundamental roles in classification of livestock based on their size and shape [18]. Several studies have been carried out for the identification of breeding objectives, selection criteria, morphological characterization and breeding practices associated with the rearing of indigenous goats in Ethiopia $[10,32]$. The diversity in gene pool and their influence of varied climatic conditions have given rise to different local ecotypes of goats which are repositories of unique genes that should be conserved for future benefits [1]. However, there are still some lacunas in the previous studies pertaining to the morphological characterization and information on morphometrical traits and besides that, structural indices of these goats have not been assessed so as to identify the type and function of the goats for which traits the goats were developed in Sidama Zone, Southern Ethiopia. Therefore, this study was designed to morphologically characterize and to assess the type and function of the indigenous goats using the structural indices and to identify variation among the goats reared in two production system in the study area.

\section{Materials and Methods}

\subsection{Description of the Study Areas}

The current study was conducted in the South Nation Nationalities and Regional State (SNNRS) that has 121 districts of which 23 are situated in Sidama Zone (Figure 1). Two districts (Aroresa and Loka Abaya) were selected for the purpose of the current study based on their potential for goat population and different production environments. The descriptions of the districts are as follows:

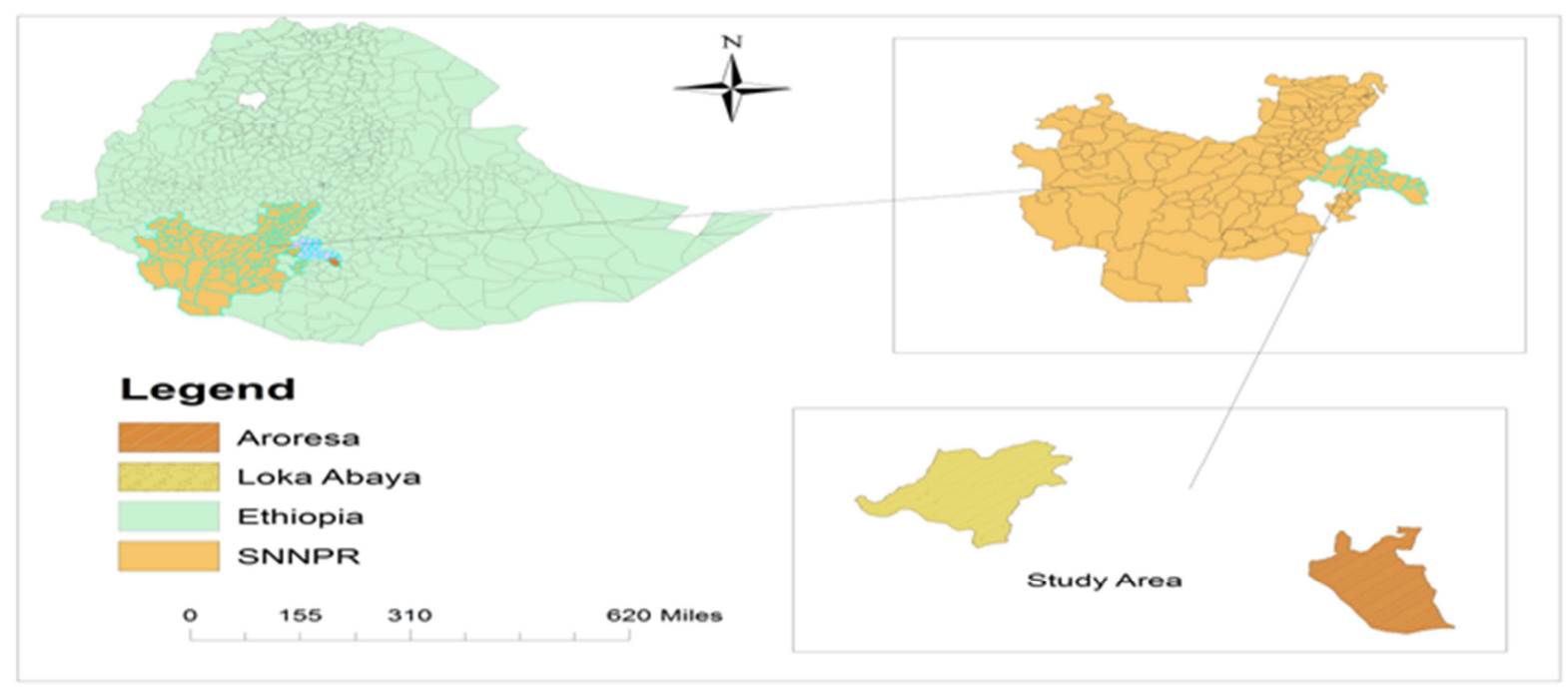

Figure 1. Map of the Study Areas.

Aroresa; - It is far from Hawassa city by $186 \mathrm{~km}$ and from Addis Ababa by $461 \mathrm{~km}$. It is situated at about $6020^{\prime}$ North Latitude and $39000^{\prime}$ East Longitude. It has variability of topography and its average rain fall is about $733 \mathrm{~mm}$ and the mean annual temperature is $18.50 \mathrm{C}$. The district covers an area of about $8,100 \mathrm{Km}^{2}$ and has 33 kebeles of which, 11 kebeles are highland while, the remained are midland
(Woinedega). The total human population of the district is estimated to be 226,631 of which, 113,731 are males and 112,900 are females. The total livestock population in the area is estimated to be 138,529 of which about 127,204 are indigenous cattle and about 11,325 are cross breed, 37,735 sheep, 20,855 goats, donkeys, 3221 horses and 375 mules. Even though livestock rearing has significant importance in 
the area, the livelihood of the farmers is mainly based on crop production this is mainly because sufficient rain fall which is received in the "kremt from April-August (ADFLDO, 2017)

Loka Abaya:-It is one of the 23 districts found in Sidama Zone and it is bordered with Guji Zone of the Oromia regional state in south, Woayita Zone, Humbo district in the east, Sidama Zone Dale and Aleta chuko district in west and Boricha district in north. The district is situated between 6014 - 7018'North latitude and 37092 - 39014'East longitude. It is far from Hawassa city by $65 \mathrm{~km}$ and represents the moist lowland with altitude varying between 1170 up to $1500 \mathrm{~m}$. a. s. 1 (LDFLDO, 2017 and IPMS, 2005). Out of the total agro-ecology of the district, $79 \%$ is estimated to be lowland, $16 \%$ midlands and $5 \%$ is desert. Annual average rain fall amount is range from 900-1400 $\mathrm{mm}$ and annual temperature amount range from $10-320 \mathrm{C}$. The total land area of the district is 119000 hectare, of which, $20.2 \%$ is crop land, $0.85 \%$ expected to be used for crops in future, $6.19 \%$ is grazing land, $70 \%$ is covered by forest and bushes, 2.63 is covered by others and 0.126 is not usable for agricultural activity. The population number of the district are 116,595 and out of these, 59786 are estimated to be males whereas, 56809 are females. The livestock population in the area is estimated to be 209,132 indigenous cows, 107, 99 indigenous bulls 152 cross breed cows and 42 cross breed bulls, 123,607 goats, 50,814 sheep, 18,065 donkeys, 192 mules and 82 horses (LDFLDO, 2017).

\subsection{Sample Size and Sampling Technique}

Stepwise purposive sampling was carried to select the kebeles. A total of six Peasant Associations (PAs), three from each district were selected for the current study. For Morphometrical measurements: 100 Does and 30 Bucks were selected randomly to carry out linear body measurements in each rural kebeles for the study, which make a total of 780 (600 Does and 180 Bucks of age yearling and above.

\subsection{Methods of Data Collection}

In each sampling site, before starting data collection the selected goat owners were briefed about the importance of the study and asked inquire permission for their willingness before any task of the study was commenced.

Data on the assessment of qualitative characters and quantitative traits were obtained according to [17] descriptor list from a total of 780 goats of either sexes or age categories. Each animal was grouped by its sex, age and sampling site. Dentition record was included, as this was the only reliable means to estimate the approximate age of animal. For the assessment of quantitative (morphometrical) traits, only those Bucks and Does aged one year and above were considered for the purpose of uniformed comparison. These age groups of goats were classified as, one pair of permanent incisors (1PPI) at age of 15- 23 months, two pairs of permanent incisor (2PPI) at age of 24-35 months, three pairs of permanent incisors (3PPI) at age of 36-48 months and four pairs of permanent incisors (4PPI) at age of over 48 months and sex groups (male and females) [40]. For qualitative traits data collection: Visual observation was made and morphological features were recorded based on breed morphological characteristics descriptor list of [17] for phenotypic characterization of goat. Each animal was identified by its sex, dentition and sampling site. Qualitative trait data on coat color pattern, coat color type, ear form, presence and absence of wattle, horn, beard, and horn shape and horn orientation and facial profile were observed and recorded for Bucks and Does separately. Morphometrical measurements were made on the quantitative traits of goat using measuring tape after restraining and holding the animals in an unforced position. All measurements are taken in the early morning prior to supply of feed and by the same personnel in each Woreda while goats are in an up-right plane during measurement. Pregnant animals were avoided in sampling because of the effect pregnancy can produce on somebody parameters especially thoracic measurements. The measurement was made on animals based on sex and age group. Animal's age classification was made using dentition technique supplemented with owner's information. The linear body measurement was made using plastic tape. Additionally, the width and depth measurement was done using a calibrated wooden caliper, while body weight of animals were measured using suspended spring or Slater weighing scale having $50 \mathrm{~kg}$ capacity with $0.2 \mathrm{~kg}$ precision.

Table 1. Methods of calculating the structural indices.

\begin{tabular}{ll}
\hline Type of index & Calculation \\
\hline Height Index & Height at withers/body length $\times 100$ \\
Rump Length Index & Length of rump/body length $\times 100$ \\
Over Increase index & Height at rump/height at withersX100 \\
Height Slope & Rump height-withers height \\
Length Index (1) & Body length/height at withers \\
Body Weight Index & Body weight/height at withers $\times 100$ \\
Length Index (2) & body length/chest (thorax) depth \\
Depth Index: & chest depth/withers height \\
Foreleg Length: & withers height - chest depth \\
Body Index & Body length $* 100 /$ chest girth \\
Body Ratio & Height at withers/Height at rump. \\
Weight & HG ${ }^{\mathrm{e} *} 80$ \\
Cephalic Index & Head width*100/head length \\
Thoracic Development & CG/WH \\
\hline
\end{tabular}

Source: $[3,8]$.

\subsection{Data Analysis}

Quantitative and qualitative data generated from field survey and on farm linear body measurements were recorded and entered into computer on a Microsoft Excel spread sheet and analyzed Statistical package for social Science (SPSS of version 20). Simple descriptive statistics compiled the observed categorical variables and the means were compared using Duncan's Multiple Range Test and the value was considered significance at $\mathrm{P}<0.05$ and $\mathrm{p}<0.01$. For adult animals, sex, location and age group of the goats were fitted 
as independent variables while body weight and linear body measurements were fitted as dependent variables. Least square means with their corresponding standard errors were calculated for each body trait over sex, age. Simple descriptive statistics compile the observed categorical variables best fitted models were selected based on coefficient of their determination $\left(\mathrm{R}^{2}\right)$, mean square error and simplicity of measurement under field condition. The collected data were classified based on sex, age and sampling site (four age groups; 1PPI, 2PPI, 3PPI and 4PPI). Mean \pm SE for body weight and linear measurement calculated using Statistical package for social Science (SPSS of version 20).

The relationship of body weight and linear body measurements estimated by Pearson correlation (done for both sexes separately to exclude sex effect).

Model $Y_{\mathrm{ijk} k}=\mu+D_{\mathrm{i}}+\mathrm{S}_{\mathrm{j}}+\mathrm{A}_{\mathrm{k}}+\mathrm{e}_{\mathrm{ijkl}}$

Where:

$\mathrm{Y}_{\mathrm{ijkl}}=\mathrm{The}$ observation on body weight and linear body measurements;

$\mu=$ Overall mean;

$\mathrm{D}_{\mathrm{i}}=$ Fixed effect of district on morphometric measurement

( (Aroresa and Loka Abaya)

$\mathrm{Si}=$ Fixed effect of sex $(1=$ male, $2=$ female $)$

$\mathrm{A}_{\mathrm{k}}=$ Fixed effect of age group (1=age group 1 (1 \&2 PPI) and $2=$ age group 2 ( $3 \& 4$ PPI)

$\mathrm{e}_{\mathrm{ijk}}=$ Random error

In addition for multiple regression,

$\mathrm{Y}=\beta 0+\beta 1 \mathrm{X} 1+\beta 2 \mathrm{X} 2+\ldots \beta \mathrm{nXn}+\mathrm{ej}$

Where:

$\mathrm{Y}=$ the response variable (body weight)

$\beta 0=$ the intercept

$\mathrm{X} 1 \ldots \mathrm{Xn}$ were the explanatory variables (whither height, rump height, body length, chest girth, ear length and horn length) $\mathrm{Xn}$

$\beta 1 \ldots \beta n$ are regression coefficients of the variables $\mathrm{X} 1 \ldots$

ej=random error

\section{Results and Discussion}

Qualitative Traits:-The findings pertaining to the qualitative traits of the Bucks and Does reared in the study areas are presented in Table 2. The study indicates that the coat color pattern is mostly plain in both the study areas. The next most common coat color pattern is patchy, which can be fallout of crossings between Bucks and Does of different colors [21]. The study also indicates that most of the goats are dark colored (black, red etc). The observations are in close accordance with those of $[25,37]$. This may be ascribed to the fact that dark colored animals usually secrete substances from the subcutaneous glands which are helpful in protecting the animals against the ecto-parasites [46]. Studies by [24] also indicated that white skinned animals are preferred in the tropics especially in the lowlands as light coat color can be helpful to protect the animals from the high temperature. The result further indicates that the Bucks and Does are horned which has both socio cultural and practical importance, as horned Bucks and Does can effectively fight against the predators [27]. The horn shape is straight and backward and upward oriented, the observations are in close accordance with those of [5]. However, the respondents need to be careful to segregate the flocks effectively as the Bucks tend to compete during the mating season and therefore may harm themselves in the process [27]. Moreover, fighting between different sexes and also age categories within sexes can have serious consequences and may even lead to fatalities within flocks. The study further indicates that the ear of both the sexes are mostly held horizontally which may be a breed character, which too is in close accordance with those of [5] for Abergelle breed of goats. The study further indicates that the head profile in most of the cases is straight (irrespective of both the sexes), most of the Bucks and Does are devoid of wattles which too are in close accordance with those of [21] from Ghana. The study further indicates that most of the Bucks have beard (irrespective of the locations) while this too may be a trait which is breed specific.

Table 2. Occurrences (\%) of some qualitative traits of goats reared in two different locations in Sidama Zone.

\begin{tabular}{|c|c|c|c|c|c|c|c|}
\hline \multirow{2}{*}{ Traits } & \multirow{2}{*}{ Class level } & \multicolumn{3}{|l|}{ Aroresa } & \multicolumn{3}{|l|}{ Lokabaya } \\
\hline & & Female (\%) & Male (\%) & Overall (\%) & Female (\%) & Male (\%) & Overall (\%) \\
\hline \multirow{3}{*}{ Coat pattern } & Plain & 74 & 70 & 73.1 & 72.3 & 65.6 & 70.8 \\
\hline & Patchy & 25 & 30 & 26.2 & 25.7 & 34.4 & 27.7 \\
\hline & Spotted & 1 & 0.0 & 0.8 & 2 & 0.0 & 1.5 \\
\hline \multirow{8}{*}{ Coat color type } & White & 18.7 & 17.8 & 18.5 & 49.3 & 50 & 49.5 \\
\hline & Black & 21.3 & 22.2 & 21.5 & 2.7 & 3.3 & 2.8 \\
\hline & Brown & 27.3 & 23.3 & 26.4 & 11.7 & 5.6 & 10.3 \\
\hline & Gray & 6.3 & 5.6 & 6.2 & 4.7 & 5.6 & 4.9 \\
\hline & Red & 0.3 & 1.1 & 0.2 & 4 & 1.1 & 3.3 \\
\hline & White +Black & 16.7 & 22.2 & 17.9 & 14.3 & 21.1 & 15.9 \\
\hline & Brown + white & 9 & 7.8 & 8.7 & 6 & 7.8 & 6.4 \\
\hline & Light red + White & 0.3 & 0.0 & 0.3 & 7.3 & 5.6 & 6.9 \\
\hline \multirow{2}{*}{ Horn } & Present & 99.3 & 100 & 99.5 & 99.7 & 100 & 99.7 \\
\hline & Absent & 0.7 & 0.0 & 0.5 & 0.3 & 0.0 & 0.3 \\
\hline \multirow{3}{*}{ Horn shape } & Straight & 81.9 & 85.6 & 82.7 & 90.6 & 71.1 & 86.1 \\
\hline & Curved & 6.4 & 6.7 & 6.5 & 8.4 & 12.2 & 9.3 \\
\hline & Spiral & 11.8 & 7.8 & 10.9 & 1 & 16.7 & 4.6 \\
\hline
\end{tabular}




\begin{tabular}{|c|c|c|c|c|c|c|c|}
\hline \multirow{2}{*}{ Traits } & \multirow{2}{*}{ Class level } & \multicolumn{3}{|l|}{ Aroresa } & \multicolumn{3}{|l|}{ Lokabaya } \\
\hline & & Female (\%) & Male (\%) & Overall (\%) & Female (\%) & Male (\%) & Overall (\%) \\
\hline \multirow{2}{*}{ Horn orientation } & Back ward & 91.3 & 96.7 & 92.5 & 93.3 & 97.8 & 94.3 \\
\hline & Oblique upward & 8.7 & 3.3 & 7.5 & 6.7 & 2.2 & 5.7 \\
\hline \multirow{3}{*}{ Ear orientation } & Horizontal & 82.2 & 82.2 & 76.2 & 68.7 & 80 & 71.3 \\
\hline & Dropped & 17.3 & 14.4 & 16.7 & 26.3 & 17.8 & 24.4 \\
\hline & Forward & 8.3 & 3.3 & 7.2 & 5 & 2.2 & 4.4 \\
\hline \multirow{3}{*}{ Facial profile } & Straight & 88 & 87.8 & 87.9 & 91.3 & 91.1 & 91.5 \\
\hline & Concave & 7 & 7.8 & 7.2 & 4 & 5.6 & 4.4 \\
\hline & Slight concave & 5 & 4.4 & 4.9 & 4.7 & 3.3 & 4.4 \\
\hline \multirow{2}{*}{ Wattle } & Present & 17.7 & 12.2 & 16.4 & 15.3 & 11.1 & 14.4 \\
\hline & Absent & 82.3 & 87.8 & 83.6 & 84.7 & 88.9 & 85.6 \\
\hline \multirow{2}{*}{ Beard } & Present & 33 & 76.7 & 43.1 & 38 & 83.3 & 48.5 \\
\hline & Absent & 67 & 23.3 & 56.9 & 62 & 16.7 & 51.5 \\
\hline
\end{tabular}

\subsection{Quantitative Traits Measured for Goats in the Study Areas}

The findings pertaining to the quantitative traits of the Does and Bucks of the different age categories across both the studied locations are presented in Tables 3 and 4. The findings show that most of the quantitative traits of the Does (aged 1 and 2 years) are higher among those which are reared at Aroresa district. This may be ascribed to the genotype by environmental interaction between the traits. This leads to better skeletal development and therefore the structural differences were observed in both locations, the differences as observed are in close accordance's with those of [16] from West Hararghe. The study further indicates that the however, there were no differences in body weight among the Does reared in the two locations. The results pertaining to the body length (BL) as among the Does in the study are in close accordance with those reported by [25] in the Does of the Bati and Borana goat breed. However, the BL as observed are higher than those of Ghana and Nuer goats as reported by [21] and [48] respectively. The body length and height at withers at any given time reflects the animal's skeletal size and body conditions. Thus, Does with long body usually have enough body capacity and uterine capacity for the fetal development [33]. The chest girth (CG) as observed in the study are in close accordance with those of [41], however the values are lower than those reported by [16]. It has been reported in a study by [35] that the animals which have higher CG have higher capacity to accommodate some of the vital organs viz. heart and liver. Studies by [22] have also indicated that $\mathrm{CG}$ and body weight of animals are highly correlated. The studies pertaining to wither height (WH) indicates that the values are in close accordance with those of [16]. However, WH are higher than those reported by [21], while higher values too were obtained by [25] in Bati and Borena goat breeds. Findings by [8] have indicates that animals with high withers, rump and long legs have good grazing ability especially in hot climates. High withers also ensure that all the vital organs are well above the blazing heat of the ground and therefore is well adapted to the lowlands [34]. The study also indicates that Does with wide the rump width (RW) and long rump length (RL) usually have high capacity for uterine and fetal development [33]. This ensures that the chances of abortion (due to large fetal size) and dystocia are low [33]. The study also indicates that the trait chest depth (CD) like that of CG is profound importance as the two traits are significantly correlated. In case of the Does it is expected that the neck circumferences (NC) should be narrow and narrowness of the neck is correlated with feminity [39]. The NC as reported in the present study is in close accordance with the values reported by [14] for Boer goat breed. However, the NC that observed in the study is higher than those of Afar goats as reported by [45]. Studies by [23] have indicated that long ear length (EL) is observed among the animals adapted to the warm climates. This is because thin skin of the ear has veins at its surface which is exposed to the atmosphere and assists in thermoregulation [23]. Thus, the longer the ear, more is the surface area and betters the thermoregulation.

The EL as reported among the Does are in close accordance with those of [4] from Shabelle Zone, South Eastern Ethiopia. The face length (FL) of the Does reported in this study is lower than those reported by [49] for Does of Maefur goat in Tigray. It has been reported that the animals with shorter snout (face length) have problems associated with respiration and are seldom able to take up strenuous exercise and graze for longer distances [9]. The head width (HW) of the Does as reported in this study are wider than those reported by [14], however the values are quite similar to those reported by [49] among Maefur goat of goats in Tigray. It has also been reported that the head width of usually narrower in the female animals and is associated with sexual dimorphism and feminity [26]. The weight of the Does aged 3-4 years as tabulated in the study are in close accordance with the findings of [2]) for indigenous goats breed in Western Ethiopia. The overall value of the trait is closely associated with the genotype and environmental interaction and the management received by the Does [12]. The results related to the average body length (BL) of the Does aged 3-4 years are in close accordance to those reported by [49] for Maefur goat of Does. However, the findings also show that the trait is higher than those reported by $[16,21]$ for Indigenous Hararghe Highland Goat Breed and Coastal Savannah and Forest Eco Zones of Ghana Goat breed respectively. The CG as observed too are in close accordance with those of [48] from Nuer Zone. The WH as observed varied across the Does reared in both the locations and the value as observed for the trait was in close accordance with those of [5, 13] for Abergelle and Central Highland Goat 
Breeds and Creole goats breed and their crossbred respectively The differences as observed may have been ascribed to the adaptability of the Does to the different systems of feeding (grazing and cut and carry system of feeding). This is because the animals which are expected to graze for long distances usually have long legs and consecutively long withers [34]. The RH values as recorded are in close accordance with those of [13] for Creole crossbred goats. The RW and RL as recorded in the study are also in close accordance with those of the [13] for Creole crossbred of goats. The study also indicated that the $\mathrm{NC}$ of the Does was in close accordance with those of
[14] Boer breed from Ataye Farm. The study also showed that the FL and HW of the Does was in close accordance with those of [14] for the Cuban Creole goats breed and their crossbred. While the FL was longer among Maefur goat as reported by [49] while the values of the HW was also wider among Maefur Does as reported by [49]. The BW of the Does varied across the studied locations, which may be ascribed to the quality of the forage available and the amount the Does received across the two locations. The $\mathrm{BW}$ as observed in the study are in consonance with the findings of [49] reported for Maefur goat in Tigray.

Table 3. Comparison of some linear body measurements (Mean \pm SE) of Does in study areas across the districts in different age groups.

\begin{tabular}{|c|c|c|c|c|c|c|}
\hline & Does age group $1 \& 2$ & & & Does age group $3 \& 4$ & & \\
\hline Traits & Aroresa & Lokabaya & P-value & Aroresa & Lokabaya & P-value \\
\hline $\mathrm{BL}$ & $62.31 \pm 0.31 * *$ & $59.96 \pm 0.30$ & 0.005 & $67.16 \pm 0.23$ & $67.04 \pm 0.21$ & 0.7 \\
\hline $\mathrm{CG}$ & $66.43 \pm 0.31 * *$ & $65.19 \pm 0.32$ & 0.007 & $71.02 \pm 0.29$ & $71.26 \pm 0.24$ & 0.5 \\
\hline WH & $62.51 \pm 0.29 * *$ & $59.83 \pm 0.26$ & 0.001 & $66.39 \pm 0.22 * *$ & $63.82 \pm 0.27$ & 0.005 \\
\hline $\mathrm{RH}$ & $65.14 \pm 0.30 * *$ & $62.34 \pm 0.28$ & 0.002 & $68.45 \pm 0.22 * *$ & $66.27 \pm 0.24$ & 0.001 \\
\hline RW & $16.13 \pm 0.14 * *$ & $14.07 \pm 0.09$ & 0.006 & $17.42 \pm 0.13 * *$ & $15.47 \pm 0.09$ & 0.009 \\
\hline RL & $18.57 \pm 014 * *$ & $16.37 \pm 0.10$ & 0.007 & $20.20 \pm 0.10 * *$ & $18.41 \pm 0.09$ & 0.004 \\
\hline $\mathrm{NC}$ & $29.22 \pm 014$ & $28.34 \pm 0.52$ & 0.12 & $31.20 \pm 0.15^{* *}$ & $30.07 \pm 0.15$ & 0.007 \\
\hline EL & $14.34 \pm 0.05$ & $14.28 \pm 0.05$ & 0.47 & $14.44 \pm 0.05$ & $14.43 \pm 0.06$ & 0.96 \\
\hline HL & $7.74 \pm 015 * *$ & $7.01 \pm 0.16$ & 0.002 & $10.03 \pm 0.21$ & $10.50 \pm 0.16$ & 0.08 \\
\hline FL & $15.54 \pm 0.06^{* *}$ & $14.10 \pm 0.07$ & 0.005 & $16.53 \pm 0.06^{* *}$ & $15.89 \pm 0.07$ & 0.002 \\
\hline HW & $10.74 \pm 0.06^{* *}$ & $9.44 \pm 0.03$ & 0.001 & $11.76 \pm 0.5^{* *}$ & $9.87 \pm 0.04$ & 0.003 \\
\hline BW & $25.28 \pm 0.24$ & $25.42 \pm 0.25$ & 0.7 & $30.06 \pm 0.25$ & $31.45 \pm 0.3^{* *}$ & 0.005 \\
\hline
\end{tabular}

The values on the same row with same age group are significantly different $*(\mathrm{P}<0.05)$ and $* *(\mathrm{P}<0.01))$; $\mathrm{BL}=\mathrm{Body}$ Length $(\mathrm{cm})$, $\mathrm{CG}=\mathrm{Chest} \mathrm{Girth}(\mathrm{cm})$, WH=Withers Height (cm), RH=Rump Height (cm), RW=Rump Width, RL=Rump Length (cm), CD=Chest Depth $(\mathrm{cm}), \mathrm{NC}=\mathrm{Neck}$ Circumference (cm), $\mathrm{EL}=$ Ear length $(\mathrm{cm}), \mathrm{HL}=$ Horn length $(\mathrm{cm}), \mathrm{FL}=$ Face Length $(\mathrm{cm}), \mathrm{HW}=$ Head Width $(\mathrm{cm}) \mathrm{BW}=$ Body weight $(\mathrm{kg})$.

The results as presented in Table 6 show that there was variation in some skeletal dimensions of the Bucks aged 1 and 2 years reared across the two locations. The differences may be ascribed to the type of nutrition available to them and this is in line with those of [12] for Turkish hair goats breed. The $\mathrm{CG}$ and $\mathrm{BL}$ are traits which are correlated with Body weight [5]. The results pertaining to the withers height of the Bucks as observed in the study are in consonance with those values reported for Maefur goats in Tigray region [49]. Differences were also observed in the $\mathrm{RH}$ and $\mathrm{RL}$ which can be ascribed to the differences in the nutrition available to them. The study also indicated that differences in $\mathrm{CD}$ of the Bucks which too are in close accordance with the findings of [4] from Shabelle Zone, South Eastern Ethiopia. However, lower CD values were also reported for the Maefur goats in Tigray [49]. The differences in HL as observed too are in close accordance with the reports of [19]. It has also been reported by that Bucks with longer horns are considered as more masculine and have an adaptive feature to fight predation especially in the tropical zones where production is characterized by extensive system [27]. The FL of the Bucks and the HW too varied across the locations and were higher among those reared at A. However, the values of the traits as observed are not in close accordance with those of Bucks of Bale breed [10]. The differences in BW as observed among the Bucks may be ascribed to the nutrition available to them. The findings are in close accordance with the observations of $[21,12]$ and among Coastal Savannah and Forest Eco-Zones of Ghana breed of goats, respectively. The results also indicated differences in NC and BW among the Bucks (aged 3 and 4 years) reared across the two studied areas are in close accordance with the findings of [14] who reported that NC and BW are highly correlated. The findings also showed that the BL of the Bucks as observed are in close accordance with of the findings reported for Maefur goat [49]. The CG as observed too did not vary across the locations and were in close accordance with those reported in the literatures [22, $10,2,25]$. The BW of the Bucks is also in close accordance with the values reported for BW of Hararghe Highland breed of goats [6].

Table 4. Comparison of some linear body measurements (Mean \pm SE) of Bucks in study areas across the districts in different age groups.

\begin{tabular}{lllllll}
\hline \multirow{2}{*}{ Traits } & \multicolumn{2}{l}{ Bucks age group 1\&2 } & \multicolumn{3}{l}{ Bucks age group 3\&4 } \\
\cline { 2 - 7 } & Aroresa & Lokabaya & P-value & Aroresa & Lokabaya \\
\hline BL & $63.73 \pm 0.54$ & $66.17 \pm 0.45^{* *}$ & 0.001 & $70.86 \pm 0.38$ & $69.67 \pm 1.05$ \\
CG & $68.26 \pm 0.45$ & $70.94 \pm 0.47^{* *}$ & 0.002 & $77.08 \pm 0.74$ & $80.16 \pm 1.22$ \\
WH & $63.72 \pm 0.40$ & $64.72 \pm 0.44$ & 0.11 & $69.17 \pm 0.61$ & $70.67 \pm 0.84$ \\
RH & $65.97 \pm 0.40$ & $67.61 \pm 0.47^{*}$ & 0.014 & $72.65 \pm 0.78$ & $73.5 \pm 0.61$ \\
RW & $15.45 \pm 0.23^{*}$ & $14.84 \pm 0.16$ & 0.03 & $18.61 \pm 0.27$ & 0.08 \\
\hline
\end{tabular}




\begin{tabular}{lllllll}
\hline \multirow{2}{*}{ Traits } & \multicolumn{2}{l}{ Bucks age group 1\&2 } & \multicolumn{3}{c}{ Bucks age group 3\&4 } \\
\cline { 2 - 7 } & Aroresa & Lokabaya & P-value & Aroresa & Lokabaya & P-value \\
\hline RL & $16.97 \pm 0.19$ & $17.86 \pm 0.19^{* *}$ & 0.008 & $20.80 \pm 0.33$ & $19.83 \pm 0.40$ & 0.22 \\
CD & $28.37 \pm 0.29$ & $29.15 \pm 0.23^{*}$ & 0.04 & $32.71 \pm 0.31$ & $33.33 \pm 0.33$ & 0.39 \\
NC & $31.7 \pm 0.3$ & $35.63 \pm 0.5 * *$ & 0.009 & $37.5 \pm 0.7$ & $42 \pm 0.57 * *$ & 0.007 \\
EL & $14.30 \pm 0.08$ & $14.31 \pm 0.06$ & 0.9 & $14.37 \pm 0.16$ & $14.83 \pm 0.40$ & 0.25 \\
HL & $9.81 \pm 0.36$ & $11.38 \pm 0.32^{* *}$ & 0.002 & $14.8 \pm 0.71$ & $17.17 \pm 1.04$ & 0.16 \\
FL & $15.78 \pm 0.12^{* *}$ & $15.03 \pm 0.11$ & 0.006 & $17.2 \pm 0.22$ & $16.5 \pm 022$ & 0.18 \\
HW & $10.82 \pm 0.09^{* *}$ & $9.93 \pm 0.06$ & 0.005 & $11.67 \pm 0.14 * *$ & $10.00 \pm 0.25$ & 0.001 \\
BW & $29.08 \pm 0.41$ & $36.09 \pm 0.61^{* *}$ & 0.001 & $38.83 \pm 0.6$ & $46 \pm 1.14^{* *}$ & 0.003 \\
\hline
\end{tabular}

The values on the same row with same age group are significantly different $*(\mathrm{P}<0.05)$ and $* *(\mathrm{P}<0.01)$; $\mathrm{BL}=\mathrm{Body}$ Length $(\mathrm{cm}), \mathrm{CG}=\mathrm{Chest} \mathrm{Girth}(\mathrm{cm})$, WH=Withers Height $(\mathrm{cm}), \mathrm{RH}=$ Rump Height $(\mathrm{cm}), \mathrm{RW}=$ Rump Width, $\mathrm{RL}=$ Rump Length $(\mathrm{cm}), \mathrm{CD}=$ Chest Depth $(\mathrm{cm})$, NC=Neck Circumference $(\mathrm{cm})$, $\mathrm{EL}=$ Ear length $(\mathrm{cm}), \mathrm{HL}=$ Horn length $(\mathrm{cm}), \mathrm{FL}=$ Face Length $(\mathrm{cm}), \mathrm{HW}=$ Head Width $(\mathrm{cm}) \mathrm{BW}=$ Bodyweight $(\mathrm{kg})$.
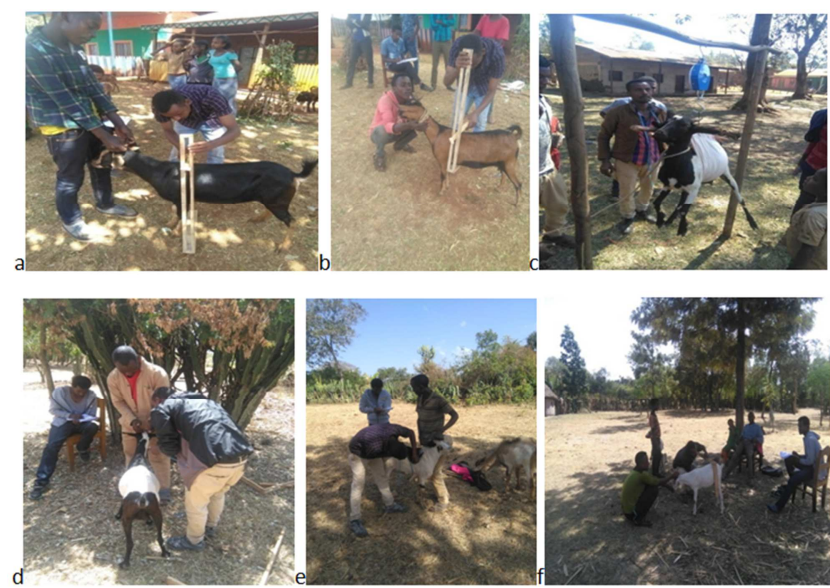

Figure 2. measuring wither height (a), Measuring Chest depth (b) Measuring body weight (c), Measuring ear length (d), Measuring chest girth (e) and Measuring rump width (f) during field work across the districts.

\subsection{Structural and Functional Indices of Goats in the Study Areas}

The results pertaining to the structural indices of the Does and Bucks in the study areas are presented in Tables 5 and 6. The findings (Height index $\mathrm{m}, \mathrm{HI}$ ) show that the length of the Bucks and the height at withers of the Does and Bucks are more or less similar, indicating the animals have a square shape, however differences $(\mathrm{P}<0,01)$ too were reported across the study areas. The findings of Length index (LI1) which also indicates that the Does have a compact shape which is near to square. It's expected that such animals have lower incidences of spinal problems vis -a -vis those who have a longer body and shorter height $[13,3]$. The height index as obtained in the current study is more or less similar to what was reported by [9] from India. The findings pertaining to the over increase index (OII) indicate that the height at rump is more or less similar to those of the withers, however there are incidences where the rump height is higher than the withers height, the findings are in close accordance with those of Banerjee (2015) from India. The front parts of such animals are usually lower than the hind part and hence are prone to dust infestations [44]. The findings are also related with the height slope (HS), and are in close accordance with those of [28]. The findings also show that the rump is approximately $25 \%$ of the whole body, which is proportionately good and thus the Does are expected to have a good uterine capacity and therefore the chances of the kid born healthy is also high $[13,14]$. The findings pertaining to the $\mathrm{BW}$ values as estimated from the index show that there are ample scope of its improvement based on the skeletal dimension, the differences as observed may be ascribed to various non-genetic factors such as lack of proper nutrition, presence of internal and external parasites and therefore there are chances of improving the same. The findings pertaining to the depth index shows that the chest depth is approximately $45 \%$ of the height of the animals, therefore such Does have a very good lung capacity and thus can graze for longer distances without getting tired and this too especially under strenuous conditions [13]. The findings from the body index values (BI) indicate that the Does and the Bucks have a very good chest capacity which is approximately $50 \%$ of the body length, this indicating that this breed of goats are ideally suitable for long distance grazing and that too at a undulating surface [13]. The findings of body ratio (BR) too correlate with the OII as the height at withers is slightly lower than those of the height of rump, the findings are in consonance with those of [28].

Table 5. Comparison of body indices (Mean \pm SE) for assessment of type and function of the Does across various age groups reared in the two different locations.

\begin{tabular}{llllll}
\hline \multirow{2}{*}{ Indices } & \multicolumn{2}{l}{ Does age group 1\&2 } & & \multicolumn{2}{l}{ Does age 3\&4 } \\
\cline { 2 - 6 } & Aroresa & Lokabaya & P-value & Aroresa & Lokabaya \\
\hline HI & $100.43 \pm 0.38$ & $99.92 \pm 0.37$ & 0.34 & $98.98 \pm 0.34^{* *}$ & $95.21 \pm 0.38$ \\
OII & $104.23 \pm 0.23$ & $104.20 \pm 0.18$ & 0.9 & $103.13 \pm 0.18^{* *}$ & $103.9 \pm 0.004$ \\
RLI & $29.8 \pm 0.18$ & $27.35 \pm 0.17 * *$ & 0.003 & $30.09 \pm 0.14^{* *}$ & $27.46 \pm 0.12$ \\
HS & $2.62 \pm 0.16$ & $2.50 \pm 0.10$ & 0.5 & $2.05 \pm 0.12$ & 0.001 \\
LI (1) & $0.99 \pm 0.00$ & $1.00 \pm 0.00$ & 0.34 & $1.01 \pm 0.00$ & 0.004 \\
BWI & $40.43 \pm 0.34$ & $42.26 \pm 0.34 * *$ & 0.005 & $45.26 \pm 0.36$ & 0.005 \\
LI (2) & $2.3 \pm 0.01$ & $2.28 \pm 0.01$ & 0.12 & $2.29 \pm 0.00$ & $4.05 \pm 0.00^{* *}$ \\
\hline
\end{tabular}




\begin{tabular}{lllllll}
\hline \multirow{2}{*}{ Indices } & Does age group 1\&2 & \multicolumn{5}{l}{ Does age 3\&4 } \\
\cline { 2 - 7 } & Aroresa & Lokabaya & P-value & Aroresa & Lokabaya & P-value \\
\hline DI & $0.43 \pm 0.00$ & $0.44 \pm 0.00$ & 0.06 & $0.44 \pm 0.00$ & $0.45 \pm 0.00^{* *}$ & 0.009 \\
BI & $93.86 \pm 0.35^{* *}$ & $92.05 \pm 0.00$ & 0.009 & $94.7 \pm 0.34$ & $94.13 \pm 0.30$ & 0.22 \\
BR & $0.96 \pm 0.00$ & $0.96 \pm 0.00$ & 0.96 & $0.97 \pm 0.00^{* *}$ & $0.96 \pm 0.00$ & 0.004 \\
W & $5314.52 \pm 24.96^{* *}$ & $5215.43 \pm 26.34$ & 0.007 & $5682.89 \pm 23.31$ & $5703.50 \pm 19.30$ & 0.49 \\
CI & $69.17 \pm 0.38^{* *}$ & $67.12 \pm 0.40$ & 0.002 & $71.13 \pm 3.23$ & $65.17 \pm 0.37$ & 0.07 \\
TD & $1.06 \pm 0.00$ & $1.09 \pm 0.00^{* *}$ & 0.004 & $1.07 \pm 0.00$ & $1.12 \pm 0.00^{* *}$ & 0.007 \\
\hline
\end{tabular}

The values on the same row with same age group are significantly different $*(\mathrm{P}<0.05)$ and $* *(\mathrm{P}<0.01) ; \mathrm{HI}=$ Height index, RLI=Rump length index, OII $=\mathrm{Over}$ increase index, HS=Height slope, LI1=Length index (1), BWI=Body weight index, LI2=Length index (2), DI=Depth index, BI=Body index ${ }^{\mathrm{a}}$ BR=Body ratio ${ }^{\mathrm{e}}$, $\mathrm{W}=$ Weight, $\mathrm{CI}=$ Cephalic Index, $\mathrm{TD}=$ Thoracic Development.

Table 6. Comparison of body indices (Mean \pm SE) for assessment of type and function of the Bucks a across the districts.

\begin{tabular}{llllll}
\hline \multirow{2}{*}{ Indices } & \multicolumn{2}{l}{ Bucks age group 1\&2 } & \multicolumn{3}{l}{ Bucks age group3\&4 } \\
\cline { 2 - 6 } & Aroresa & Lokabaya & P-value & Aroresa & Lokabaya \\
\hline HI & $100.17 \pm 0.53$ & $97.98 \pm 0.50$ & 0.004 & $97.63 \pm 0.84$ & $101.55 \pm 1.98$ \\
OII & $103.54 \pm 0.17$ & $104.47 \pm 0.26 * *$ & 0.009 & $105.04 \pm 0.69$ & $104.03 \pm 0.60$ \\
RLI & $28.10 \pm 0.32 * *$ & $25.67 \pm 0.26$ & 0.001 & $29.33 \pm 0.42$ & $28.49 \pm 0.68$ \\
HS & $2.25 \pm 0.10$ & $2.8 \pm 0.17 * *$ & 0.006 & $3.48 \pm 0.48$ & $2.83 \pm 0.40$ \\
LI $(1)$ & $0.99 \pm 0.00$ & $1.02 \pm 0.00^{* *}$ & 0.002 & $1.02 \pm 0.00$ & 0.07 \\
BWI & $45.62 \pm 0.55$ & $55.5 \pm 0.69 * *$ & 0.001 & $56.15 \pm 0.73$ & $0.98 \pm 0.02$ \\
LI $(2)$ & $2.25 \pm 0.01$ & $2.27 \pm 0.01$ & 0.25 & $2.17 \pm 0.02$ & $0.15 \pm 1.91 * *$ \\
DI & $0.44 \pm 0.00$ & $0.45 \pm 0.00$ & 0.23 & $0.47 \pm 0.00$ & $2.09 \pm 0.03$ \\
BI & $93.37 \pm 0.55$ & $93.32 \pm 0.33$ & 0.94 & $92.10 \pm 0.73 *$ & $0.47 \pm 0.00$ \\
BR & $0.96 \pm 0.00^{*}$ & $0.95 \pm 0.00$ & 0.02 & $0.95 \pm 0.00$ & $87.04 \pm 2.16$ \\
W & $5461.33 \pm 36.37$ & $5677.17 \pm 37.69 * *$ & 0.001 & $6166.67 \pm 59.24$ & $0.96 \pm 0.00$ \\
CI & $68.75 \pm 0.55^{* *}$ & $66.14 \pm 0.50$ & 0.001 & $67.93 \pm 0.67 * *$ & 0.001 \\
TD & $1.07 \pm 0.00$ & $1.09 \pm 0.00^{* *}$ & 0.002 & $1.11 \pm 0.00$ & 0.00 \\
\hline
\end{tabular}

The values on the same row with same age group are significantly different $*(\mathrm{P}<0.05)$ and $* *(\mathrm{P}<0.01)$; HI=Height index, RLI=Rump length index, OII $=\mathrm{Over}$ increase index, HS=Height slope, $\mathrm{LI} 1=$ Length index (1), BWI=Body weightindex, LI2=Length index (2), DI=Depth index, BI=Body index ${ }^{\mathrm{a}}, \mathrm{BR}=\mathrm{Body}$ ratio ${ }^{\mathrm{e}}$, $\mathrm{W}=$ Weight, $\mathrm{CI}=$ Cephalic Index, $\mathrm{TD}=$ Thoracic Development.

\subsection{Predicting Body Weight from the Value of Correlated Linear Body Measurements}

The pertaining to the assessment of body weight of the Does using the morphometrical traits is presented in Table 7. The findings indicate that the most important trait considered for assessing the BW of the Does across the study areas was the CG followed by other skeletal parameters; the observations are in close accordance with previous reports $[22,47]$. This may be ascribed to the fact that animals with better thoracic development have higher weight of some vital organs such as heart and lungs [23]. The traits such as BL have also a very important implication on the $\mathrm{BW}$ of the Does as longer the body, so is the higher the BW of the Does.

Table 7. Body weight estimation for Does from different morphometrical traits in different age groups across the districts.

\begin{tabular}{|c|c|c|c|}
\hline Location & Age group & $\mathbf{R}^{2}$ - adj & Equations \\
\hline \multirow{3}{*}{ Aroresa } & \multirow{3}{*}{ Age group $1 \& 2$} & 0.62 & $Y=-16.21+0.62(\mathrm{CG})$ \\
\hline & & 0.64 & $Y=-12.47+0.53(\mathrm{CG})+0.29(\mathrm{BL})$ \\
\hline & & 0.65 & $Y=-14.41+0.51(\mathrm{CG})+0.24(\mathrm{BL})+0.20(\mathrm{RW})$ \\
\hline \multirow{4}{*}{ Aroresa } & \multirow{4}{*}{ Age group $3 \& 4$} & 0.54 & $Y=-18.47+0.68(C G)$ \\
\hline & & 0.66 & $Y=-27.45+0.45(\mathrm{CG})+0.86(\mathrm{CD})$ \\
\hline & & 0.71 & $\mathrm{Y}=-37.55+0.35(\mathrm{CG})+0.70(\mathrm{CD})+0.32(\mathrm{BL})$ \\
\hline & & 0.72 & $\mathrm{Y}=-38.23+0.30+(\mathrm{CG})+0.65(\mathrm{CD})+0.29(\mathrm{BL})+0.25(\mathrm{NC})$ \\
\hline \multirow{6}{*}{ Lokabaya } & \multirow{6}{*}{ Age group $1 \& 2$} & 0.64 & $Y=-17.04+0.65(\mathrm{CG})$ \\
\hline & & 0.70 & $\mathrm{Y}=-21.56+0.41(\mathrm{CG})+0.34(\mathrm{BL})$ \\
\hline & & 0.74 & $\mathrm{Y}=-20.07+0.34(\mathrm{CG})+0.34(\mathrm{BL})+0.11(\mathrm{NC})$ \\
\hline & & 0.75 & $\mathrm{Y}=-17.6+0.32(\mathrm{CG})+0.30(\mathrm{BL})+0.12(\mathrm{NC})+0.18(\mathrm{HL})$ \\
\hline & & 0.75 & $\mathrm{Y}=-13.7+0.33(\mathrm{CG})+0.28(\mathrm{BL})+0.15(\mathrm{NC})+0.27(\mathrm{HL})-0.35(\mathrm{RL})$ \\
\hline & & 0.77 & $\mathrm{Y}=-13.92+0.28(\mathrm{CG})+0.29(\mathrm{BL})+0.15(\mathrm{NC})+0.26(\mathrm{HL})-0.42(\mathrm{RL})$ \\
\hline \multirow{5}{*}{ Lokabaya } & \multirow{5}{*}{ Age group $3 \& 4$} & 0.48 & $Y=-23.36+0.77(\mathrm{CG})$ \\
\hline & & 0.61 & $\mathrm{Y}=-40.06+0.52(\mathrm{CG})+0.50(\mathrm{BL})$ \\
\hline & & 0.66 & $Y=-46.5+0.44(\mathrm{CG})+0.48(\mathrm{BL})+0.89(\mathrm{FL})$ \\
\hline & & 0.67 & $\mathrm{Y}=-47.46+0.42(\mathrm{CG})+0.43(\mathrm{BL})+0.68(\mathrm{FL})+0.14(\mathrm{WH})$ \\
\hline & & 0.68 & $\mathrm{Y}=-46.32+0.37(\mathrm{CG})+0.39(\mathrm{BL})+0.66(\mathrm{FL})+0.12(\mathrm{WH})+0.20(\mathrm{NC})$ \\
\hline
\end{tabular}

$\mathrm{R}^{2}$ adj=adjusted coefficient of determination; $\mathrm{CG}=$ chest girth, $\mathrm{BL}=$ body length, $\mathrm{NC}=$ neck circumference, $\mathrm{WH}=$ wither height, $\mathrm{RW}=\mathrm{rump}$ width, $\mathrm{RL}=\mathrm{rump}$ length, $\mathrm{CD}=$ chest depth, $\mathrm{HL}=$ Horn length, $\mathrm{FL}=$ Face length, $\mathrm{HW}=$ head width, $\mathrm{EL}=$ ear length. 
The results pertaining to the assessment of body weight of the Does and Bucks reared across the two study areas taking into consideration the morphometrical traits as presented in Table 8 . The regression equations indicate that the trait which is primordial importance is the $\mathrm{CD}$ which too is correlated with the CG. The results also indicate that the trait $\mathrm{NC}$ is also of importance as the Bucks which have thicker necks usually have higher BW. The study also indicates that WH too is of importance as the animals with longer withers usually have strong fore and hind legs [35]. Long and thick femur, tibia and metatarsus have higher surface areas for muscle attachment and is hence correlated with body weight [8].

Table 8. Body weight estimation for Bucks from different morphometrical traits in different age groups across the districts

\begin{tabular}{llll}
\hline Location & Age group & $\mathbf{R}^{2}$ - adj & Equations \\
\hline \multirow{3}{*}{ Aroresa } & \multirow{2}{*}{ Age group 1\&2 } & 0.73 & $\mathrm{Y}=-5.33+1.21(\mathrm{CD})$ \\
& & 0.81 & $\mathrm{Y}=-19.6+0.72(\mathrm{CD})+0.41(\mathrm{CG})$ \\
& Age group 3\&4 & 0.85 & $\mathrm{Y}=-13.68+0.80(\mathrm{CD})+0.54(\mathrm{CG})-0.26(\mathrm{WH})$ \\
& & 0.67 & $\mathrm{Y}=11.37+0.73(\mathrm{NC})$ \\
\multirow{3}{*}{ Lokabaya } & Age group 1\&2 & 0.82 & $\mathrm{Y}=-47.41+1.17(\mathrm{CG})$ \\
& & 0.86 & $\mathrm{Y}=-54.36+0.92(\mathrm{CG})+0.39(\mathrm{WH})$ \\
& Age group 3\&4 & 0.87 & $\mathrm{Y}=-49.29+0.85(\mathrm{CG})+0.26(\mathrm{WH})+0.22(\mathrm{NC})$ \\
\hline
\end{tabular}

$\mathrm{R}^{2}$ adj.= adjusted coefficient of determination; $\mathrm{CG}=$ chest girth, $\mathrm{NC}=$ neck circumference, $\mathrm{WH}=$ wither height, $\mathrm{RL}=\mathrm{rump}$ length, $\mathrm{CD}=$ chest depth .

\section{Conclusion and Recommendations}

As the results obtained by phenotypic characterization of this study indicate that, most of linear body measurements and body weight, coat color type of goats and some value of structural indices are varied across the districts and as the result of this, there are possibilities for within breed selection among the goats reared across the studied areas. The possible reason for the variation might be due to the difference of location or agro ecology. Structural indices calculated from linear measurements indicated that the Bucks age groups 3 and 4 reared in Lokabaya have good thoracic development than any other age and sex group across the districts. Most important traits obtained across the districts in the study area, which are highly correlated with their body weight and used for future to assess the body weight when a measuring balance is not available were $\mathrm{CG}, \mathrm{CD}, \mathrm{NC}$ and $\mathrm{BL}$, of which $\mathrm{CG}$ was the prominent one. Therefore, findings of the current study can be used as an input by the researchers to estimate body weight in the area where the measuring balance is not available. Characterization which is done only on a phenotypic basis is not enough to clearly sate the variation; so that, the further characterizing at molecular level is important hence; it provides sufficient information and enables clearly to identify the existing goat breeds in the study areas.

\section{References}

[1] Adebambo, O. A., (2004). Animal genetics and the quality of life. Proceedings of the $29^{\text {th }}$ Annual Conference of the Genetics Society of Nigeria, 11-14 Oct. 2004. Abeokuta, Nigeria, 4253.

[2] Ahmed S, Kefelegne K, Kefena E (2015). Breeding Objective, Selection Criteria and Breeding Practice of Indigenous Goats in Western Ethiopia: Implications for Sustainable Genetic Improvement. Greener Journal of Agricultural Sciences. 5
(5): 167-176http://doi.org/10.15580/GJAS.2015.5.072715105.

[3] Alderson, G. L. H. (1999). The development of a system of linear measurements to provide an assessment of type and function of beef cattle. Animal Genetic Resources Information, 25: 45-55.

[4] Alefe Takele, (2014). Characterization of indigenous goat types and their production system in Shabelle Zone, South Eastern Ethiopia, 130pp.

[5] Alubele Alemu, (2015). On-Farm Phenotypic Characterization and Performance Evaluation of Abergelle and Central Highland Goat Breeds as an Input for Designing CommunityBased Breeding Program, Haramaya University, Ethiopia. $147 \mathrm{p}$.

[6] Andersson, L., Haley, C. S., Ellegren, H., Knott, S. A., Johansson, M., Andersson, K., Andersson-Eklund, L., EdforsLilja, I., Fredholm, M., Hansson, I., Hakansson, J. \&Lundstrom, K., (1994). Genetic mapping of quantitative trait loci for growth and fatness in pigs. Science, 263: 17711774.

[7] Aschalew Tsegahun., Sisay Lemma., Ameha Sebsibe, Abebe Mekoya and Zinash Seleshi, (2000). National Goat Research Strategies in Ethiopia. P. 1-5. In: Merkel R. C, Girma Abebe and A. L, Goetsch (Eds). The opportunities and Challenges of enhancing goat production in East Africa 10-12 November 2000. Debub University, Awasa, Ethiopia.

[8] Banerjee S., (2015). Body Indices of Garole Sheep Reared in West Bengal India. Zoological Society, Kolkata, India, ISSN 0373-5893.

[9] Banerjee, S., Mohamed B. A. and GirmaT. (2014). Studies on morphometrical traits of Boran bulls reared on two feedlots in Southern Ethiopia. Animal Genetic Resources, 54: 53-63.

[10] Belete Asefa, (2013). On Farm Phenotypic Characterization of Indigenous Goats Type and Their Production System In Bale Zone of Oromia Region, Ethiopia, and MSc. Thesis Submitted to the School of Graduate Studies of Haramaya University, Ethiopia. 116pp.

[11] Belete Shunkute, (2009). Production and marketing system of small ruminants in Goma district of Jimma western Ethiopia. Hawassa University, Ethiopia. pp144. 
[12] Cam MA, Olfaz M, Soydan E (2010). Possibilities of using morphometric characteristics as a tool for body weight prediction in Turkish hair goats (Kilkeci). Asian Journal of Animal and Veterinary Advances, 5 (1): 52-59.

[13] Chaco'n, Edilberto, Fernando Macedo, Francisco Vela'zquez, Samuel Rezende Paiva, Eliecer Pineda, and Concepta McManus. (2011). Morphological measurements and body indices for Cuban Creole goats and their crossbreds. Revista Brasileria de Zootecnia. 40 (8): 1671-1679.

[14] Chiemela P. N, Sandip B. Egbu C. F, Akpolu E. S and Ugbo E. H. (2015). Some Morphometric Traits of Boer, Central Highland and Their F1 Cross breed Goats Reared at Ataye Farm, Ethiopia. International Journal of Advanced Academic Research $\mid$ Sciences and Technology |. 1, (3).

[15] CSA (Central Statistical Agency of the Federal Democratic Republic of Ethiopia), Agricultural Sample Survey of (2016/17), Volume II, Report on Livestock and Livestock Characteristics (Private Peasant Holdings), Central Statistical Agency, Addis Ababa, Ethiopia.

[16] Dereje Tsegaye, Berhanu Belay and Aynalem Haile, (2013). Morphological Characterization of indigenous Hararghe highland Goat breed in their native environment, West Hararghe, Ethiopia. American-Eurasian Journal of Scientific Research. 8 (2): 72-79.

[17] FAO (Food and Agricultural Organization), (2012). Phenotypic characterization of animal genetic resources. FAO Animal Production and Health Guidelines No. 11. Rome.

[18] Ferra J. C., S. Cieslak, R. S. Filho, C. McManus, C. L. Martins, J. R. B. Sereno, (2010). Weight and age at puberty and their correlations with morphometric measurements in crossbreed breed Suffolk Ewe lambs. Revista Brasileira de Zootecnia 39: pp134-141.

[19] Gatew, H., Hassen H., Kebede K., Haile A., Lobo, R. N. B. Yetayew A., and Rischkowsky B. (2015). Husbandry practices and phenotypic characteristics of indigenous goat populations in Ethiopia. African Journal of Agricultural Research, 12 (36), pp. 2729-2741.

[20] Groeneveld L. F., J. A. Lenstra, H. Eding, M. A. Toro, B Scherf, D. Pilling, R. Negrini, E. K. Finlay, H. Jianlin, E. Groeneveld, S. Weigend, (2010). The GLOBALDIV Consortium. 2010. Genetic diversity of farm animals a review. Animal Genetics, 41 (1) pp 6-31.

[21] Hagan J. K., Apori S. O., Bosompem M., Ankobea G. and Mawuli A. (2012). Morphological Characteristics of Indigenous Goats in the Coastal Savannah and Forest EcoZones of Ghana. J Anim Sci Adv 2012, 2 (10).

[22] Halima Hassen, Michael Baum, Barbara Rischkowsky and Markos Tibbo, (2012). Phenotypic characterization of Ethiopian indigenous goat populations. African. JournalofBiotechnology11 (73), pp13838-13846.

[23] Hammond, J. Jr., Ian, L. M. \& Terence, J. R. (1971). Hammond's farm animals. U. K., Edward Arnold. Hansen, P. J. (1990). Effects of coat colour on physiological responses to solar radiation in Holsteins. Vet. Rec., 127: 333.

[24] Hensen, P. J. (1990). Effects of coat colour on physiological responses to solar radiation in Holsteins. Vet. Rec., 127: 333.
[25] Hulunim Gatew, (2014). On-Farm Phenotypic Characterization and Performance Evaluation of Bati, Borena and Short Eared Somali Goat Populations of Ethiopia. MSc thesis, Submitted to the School of Graduate Studies of Haramaya University, Ethiopia. 140p.

[26] Isaac J. L., (2005). Potential causes and life-history consequences of sexual size dimorphism inmammals. Mammal Review, 35: 101-115.

[27] Katongole JBD, Sebolai B, Madimabe MJ (1996). Morphological characterization of the Tswana goat. In: S. H. B. Lebbie and E. Kagwini (ed.) Small Ruminant Research and Development in Africa. Proc. 3rd Biennial Conference of the African Small Ruminant Research. Network, UICC, Kampala, Uganda. 5-9 Dec. 1994. pp. 43-46.

[28] Khargharia, G. Kadirvel, G. Kumar, S. Doley, P. K. S Bharti and Mukut Das, (2015). Principal Component Analysis of Morphometrical Traits of Assam Hill Goat in Eastern Himalayan India. The Journal of Animal \& Plant Sciences, 25 (5), pp 1251-1258.

[29] Kosgey, I. S., Baker, R. L., Udo, H. M. J. and van Arendonk, J. A. M., (2006). Successes and failures of small ruminant breeding programs in the tropics: a review. Small Ruminant Research, 61: 13-28.

[30] Lanari M. R, H. Taddeo, E. Domingo, M. P. Centeno, L. Gall, (2003). Phenotypic differentiation of exterior traits in local Criollo goat population in Patagonia (Argentina). ArchivTierzuchDummerstorf. 46: pp 347-356.

[31] Le Roy, P., Naveau, J., Elsen, J. M. \& Sellier, P., (1990). Evidence for a new major gene influencing meat quality in pigs. Genetical Research, 55: 33-40.

[32] Mahilet Dawit, (2012). Characterization of Hararghe Highland Goat and Their Production System in Eastern Hararghe. An M. Sc. Thesis presented to Haramaya University. Dire Dawa, Ethiopia.

[33] Mekete, G., (2016). Studies on some morphological traits and structural indices of Woyito-Guji goats reared at Nyangatom and Malle woreda of SNNPRS, Ethiopia. MSc. Thesis Hawassa University College of Agriculture.

[34] Moshood Abiola, (2015). Zoo technical Index Analysis of West African Dwarf Rams in Southwestern Nigeria. Agricutura Topica Et Subtropica. 48 (1-2) 2015.

[35] Mwacharo, J. M., Okeyo, A. M., Kamande, G. K. \& Rege, J. E. O., (2006). The small East African shorthorn zebu cows in Kenya. Linear body measurements. Tropical. Animal. Health Production. V 38: 65-74.

[36] Okpeku, M., A. Yakubu, S. Peters, M. Ozoje C. Ikeobi, O. Adebambo, I. Imumorin, (2011). Application of Multivariate Principal Component Analysis to Morphological Characterization of Indigenous Goats in Southern Nigeria. ActaargiculturaeSlovenica, 98 (2): 101-109.

[37] Oseni S, Sonaiya B, Omitogun G, Ajayi A, Muritala I., (2006). West African Dwarf goat production under village conditions: I. Characterization and the establishment of breed standards. Conference on International Agricultural Research for Development University of Bonn, Tropentag. 11-13 October.

[38] Tadelle Dessie, Workneh T., (2007). Ethiopia Goat production: A case study of CD-ROM encyclopedia use. ILRI. 
[39] Takele T., (2005). On-farm Phenotypic Characterization of Sheko Breed of Cattle and their Habitat in Bench Maji Zone, Ethiopia. MSc Thesis, Haramaya University, Ethiopia. 105Pp.

[40] Tatiana, S., (1999). Teeth and Age of the Goat. New York state 4-h meat goat project fact sheet 11, Cornell University, Ithaca, No, 14853.

[41] Tesfaye Desalew, (2008). Assessment of feed resources and rangeland condition in Metema district of North Gondar Zone, Ethiopia. An MSc Thesis Presented to the School of Graduate Studies of Haramaya University, Haramaya. Pp117.

[42] TesfayeAlemu (2004). Genetic characterization of indigenous goat population of Ethiopia using microsatellite DNA markers. A Thesis submitted to the National Dairy Research Institute (Deemed University) Karnal (Haryana), India. 258pp.

[43] Tesfaye Tsegaye, (2009). Characterization of Goat Production Systems and On- Farm Evaluation of the Growth Performance of Grazing Goats Supplemented With Different Protein Sources in Metema, Amhara Region, Ethiopia. MSc Thesis, Submitted to the School of Graduate Studies of Haramaya University, Ethiopia. pp108.

[44] Tewelde G., (2016). Studies on Morphometric Characteristics, Performance and Farmers' Perceptions on Begait Cattle Reared in Western Tigray, Ethiopia. MSc Thesis. Hawassa University. Ethiopia. 51pp.
[45] Theodros Tekle, (2014). Predicting live weight using body measurements in Afar goats in north eastern Ethiopia.

[46] Toth Z, Kaps M, Solkner J, Bodo I, Curik I., (2006). Quantitative genetic aspects of coat colour in horses. Journal of Animal Science, 84: 2623-2628.

[47] Tsegaye, D., B. Belay and A. Haile (2013). Linear body measurements as predictor of body weight in Hararghe Highland Goats under Farmers Environment: Ethiopia. Global Vet. 11 (5): 649-656.

[48] Tsigabu Gebreselassie, (2015). Phenotypic Characterization of Goat type and Their Husbandry Practices in Nuer Zone of Gambella People Regional State, South Western Ethiopia 93pp.

[49] Weldeyesus Gebreyowhens and Rohatash Kumar, (2017). Phenotypic characterization of indigenous Maefur goat population in Tigray, Northern Ethiopia. International Journal of Biodiversity and Conservation. 9 (5). 130-145.

[50] Tsedey Azeze, Zelalem Yilma, Ajebu Nurfeta and Haile Welearegay, (2015). Utilization and quality of goat milk in Hadiya zone, Southern Ethiopia, Global journal of Food Science and Technology, Vol. 3 (6), pp. 197-203, November, 2015. 